Tersedia online di: http://ejournal-balitbang.kkp.go.id/index.php/jra

\title{
EFEKTIVITAS EKSTRAK DAUN CIPLUKAN (Physalis angulata L.) TERHADAP SISTEM KEKEBALAN TUBUH IKAN NILA (Oreochromis niloticus)
}

\author{
Yusrika Octarina, Eva Prasetiyono\#, Dwi Febrianti, dan Robin \\ Jurusan Akuakultur, Universitas Bangka Belitung \\ Jl. Kampus Terpadu UBB, Kel. Balunijuk, Kec. Merawang, Balun Ijuk, Merawang, \\ Kab. Bangka, Kepulauan Bangka Belitung 33172
}

(Naskah diterima: 11 Mei 2018; Revisi final: 24 Oktober 2018; Disetujui publikasi: 25 Oktober 2018)

\begin{abstract}
ABSTRAK
Penelitian ini bertujuan untuk mengetahui efektivitas ekstrak daun ciplukan (Physalis angulata) sebagai imunostimulan dalam meningkatkan jumlah leukosit dan aktivitas fagositosis pada ikan nila. Ikan nila yang digunakan berukuran panjang 10-12 cm dan bobot 70-90 g. Ikan tersebut diperoleh dari pembudidaya ikan nila di Desa Riding Panjang Kecamatan Merawang. Penelitian ini menggunakan Rancangan Acak Lengkap tunggal. Rancangan ini terdiri atas lima perlakuan (P), yaitu $\mathrm{P} 1=$ kontrol positif (penyuntikkan dengan larutan fisiologis), $\mathrm{P} 2=4 \%(\mathrm{v} / \mathrm{v})(1 \mathrm{~mL}$ ekstrak $+24 \mathrm{~mL}$ akuades $), \mathrm{P} 3=8 \%(\mathrm{v} / \mathrm{v})(2 \mathrm{~mL}$ ekstrak +23 $\mathrm{mL}$ akuades), $\mathrm{P} 4=12 \%(\mathrm{~V} / \mathrm{v})(3 \mathrm{~mL}$ ekstrak $+22 \mathrm{~mL}$ akuades $)$ dan $\mathrm{P} 5=$ kontrol negatif (tanpa penyuntikan). Ekstrak ciplukan diinjeksikan sebanyak $0,1 \mathrm{~mL}$ pada setiap ekor ikan secara intra-muskular. Indikator imun yang diamati adalah jumlah total leukosit dan aktivitas fagositosis. Data dianalisis menggunakan analisis sidik ragam (ANOVA). Hasil yang menunjukkan pengaruh antara perlakuan, selanjutnya dianalis dengan uji wilayah berganda duncan. Hasil penelitian menunjukkan bahwa ekstrak ciplukan dapat meningkatkan jumlah leukosit dan aktivitas fagositosis. Dosis terbaik dalam meningkatkan respon imun adalah dosis ekstrak P4 $=12 \%(\mathrm{v} / \mathrm{v})$ ekstrak dengan jumlah total leukosit $(12,43 \times 108 \mathrm{sel} / \mathrm{mL})$ dan aktivitas fagositosis $(46,67 \%)$.
\end{abstract}

\section{KATA KUNCl: Physalis angulata; respon imun; aktivitas fagositosis; jumlah leukosit}

ABSTRACT: The efectiveness of the extract ciplukan leaves (Physalis angulata $L$.) on the immune system of nile tilapia (Oreochromis niloticus). By: Yusrika Octarina, Eva Prasetiyono, Dwi Febrianti, and Robin

The aim of this research was to determined the effectivity of the extract Physalis angulata as immunostimulant on the amount of total leucocyte count and phagocytosis activity of niletilapia. The tested fishes were niletilapia with size of, 10-12 cm in total length, and 70-90 $\mathrm{g}$ in weight. The fish were obtained from fish farmers in Riding Panjang village Merawang Sub District. The research was designed in single completely randomized design. There were five levels of treatment $(\mathrm{P})$, with $\mathrm{P}=$ positive control (injected with physiological solution), $\mathrm{P} 2=4 \%(\mathrm{v} / \mathrm{v})(1 \mathrm{~mL}$ extract $+24 \mathrm{~mL}$ aquadest), $\mathrm{P} 3=8 \%(\mathrm{v} / \mathrm{v})(2 \mathrm{~mL}$ extract $+23 \mathrm{~mL}$ aquadest $), \mathrm{P} 4=12 \%(\mathrm{v} / \mathrm{v})(3 \mathrm{~mL}$ extract $+22 \mathrm{~mL}$ aquadest $)$ and $\mathrm{P} 5=$ negative control (without injection). The extract Physalis angulata L. was injected intramuscularlyat a dose of $0.1 \mathrm{~mL}$ per fish. The immune indicators observed weretotal leucocyte count and phagocytosis activity). Data analyzed by using analysis of variant (Anova). if there were any significant different between the treatment, analysis continued by duncan"s multiple range test. The results of the research showed that the extract could increase the amount of total leucocyte count and phagocytosis activity. The ciplukan leaves at a dose of $12 \%(\mathrm{v} / \mathrm{v})$ were the most effective dose in enhancing total leucocyte (12.43 x $108 \mathrm{cel} / \mathrm{mL})$ and phagocytosis activity $(46.67 \%$.

\section{KEYWORDS: Physalis angulata; immune response; phagocytosis activity; total leucocyte count}

\footnotetext{
\# Korespondensi: Jurusan Akuakultur, Universitas Bangka Belitung. Jl. Kampus Terpadu UBB, Kel. Balunijuk, Kec. Merawang, Balun ljuk, Merawang, Kab. Bangka, Kepulauan Bangka Belitung 33172 Tel. + 628117178769

E-mail: evaintegral@gmail.com
} 


\section{PENDAHULUAN}

Ikan nila (Oreochromis niloticus) merupakan salah satu ikan budidaya air tawar yang mempunyai prospek yang baik. Ikan nila memilliki sifat yang menguntungkan antara lain mudah berkembang biak dan pertumbuhannya relatif cepat. Kelebihan yang dimiliki ikan nila ini menyebabkan ikan nila banyak dibudidayakan dan memiliki permintan pasar yang cukup tinggi. Oleh karena itu, banyak pembudidaya menerapkan sistem budidaya secara intensif untuk meningkatkan jumlah produksi ikan nila (Pasaribu et al., 2015).

Usaha budidaya secara intensif dapat menyebabkan munculnya perubahan lingkungan budidaya akibat tingginya pencemaran dan kesalahan penanganan budidaya, sehingga memicu timbulnya masalah penyakit. Serangan penyakit pada ikan budidaya akan menyebabkan kerugian ekonomi bagi pembudidaya. Pencegahan penyakit dapat dilakukan dengan beberapa cara seperti pemberian antibiotik, vaksin, dan imunostimulan (Payung \& Hengky, 2015).

Dewasa ini, kontrol penyakit banyak dilakukan dengan menggunakan bahan al ami atau tanaman obat sebagai sumber imunostimulan. Tanaman ciplukan (Physalis angulata L.) merupakan tanaman yang berpotensi sebagai imunostimulan. Kandungan kimia yang terdapat dalam daun ciplukan antara lain flavonoid sebanyak $0,33 \%$ tanin $0,93 \%$ saponin $0,30 \%$ dan polifenol 0,23\% (Astuti, 2016). Penelitian yang dilakukan oleh Effendi \& Harti (2014) menggunakan ekstrak etanol daun ciplukan yang diberikan melalui pakan pada mencit dengan dosis 4\% 8\% 12\%v/v dapat meningkatkan aktivitas IgM (imunoglobulin). Kandungan yang terdapat dalam daun ciplukan seperti flavonoid, saponin, dan tanin memiliki sifat imunostimulator. Imunostimulator merupakan senyawa yang dapat meningkatkan sistem imun, seperti halnya pada mencit yang ditandai dengan meningkatkatnya aktivitas IgM (imunoglobulin). Penelitian ini perlu dilakukan untuk mengetahui tingkat efektivitas ekstrak daun ciplukan terhadap sistem kekebalan tubuh ikan nila secara non spesifik yang diberikan melalui metode injeksi.

\section{BAHAN DAN METODE}

\section{Ekstrak Daun Ciplukan}

Daun ciplukan yang digunakan dalam penelitian ini adalah daun keempat dan kelima dari pucuk. Daun yang telah dikumpulkan, dicuci bersih kemudian ditiriskan. Pengeringan daun dilakukan dengan cara dianginkan selama 5 hari. Daun yang telah dikeringkan selanjutnya dihaluskan menggunakan blender dan disaring sehingga diperoleh serbuk halus (simplisia).

Pembuatan ekstrak daun ciplukan dilakukan secara meserasi dengan merendam simplisia dalam alkohol 96\% selama 3 hari. Simplisia disaring setelah 3 hari. Ekstrak yang diperoleh diuapkan dengan rotary evaporator pada tekanan $175 \mathrm{mbar}$, suhu $60^{\circ} \mathrm{C}$ dan kecepatan putaran $80 \mathrm{rpm}$ (Arifin et al., 2009). Ekstrak alkohol ciplukan dibuat dalam dosis $4 \%(\mathrm{v} / \mathrm{v}), 8 \%(\mathrm{v} / \mathrm{v})$, dan $12 \%$ (v/v) (Effendi \& Harti, 2014). Pembuatan dosis 4\%(v/v) daun ciplukan adalah dengan melarutkan $1 \mathrm{~mL}$ ekstrak cair daun ciplukan ke dalam akuades hingga $25 \mathrm{~mL}$. Pembuatan ekstrak dengan dosis 8\%(v/v) dan 12\%(v/ v) dilakukan dengan cara yang sama yaitu dengan melarutkan $2 \mathrm{~mL}$ dan $3 \mathrm{~mL}$ ekstrak cair daun ciplukan ke dalam akuades hingga $25 \mathrm{~mL}$.

\section{Ikan Uji}

Hewan uji yang digunakan adalah ikan nila yang sehat dengan panjang 10-12 cm dan bobot 70-90 g. Ikan berasal dari pembudidaya ikan nila di Desa Riding Panjang Kecamatan Merawang. Sebanyak 180 ekor ikan diaklimatisasi dalam akuarium dengan ukuran 90 $\mathrm{cm} \times 60 \mathrm{~cm} \times 50 \mathrm{~cm}$ selama 14 hari.

\section{Uji in vivo}

Pengujian in vivo pemberian ekstrak daun ciplukan pada ikan nila dilakukan dengan tiga perlakuan dosis berbeda dan dua perlakuan kontrol (P). Pemberian ekstrak daun ciplukan dilakukan dengan cara injeksi sebanyak 0,1 mL secara intramuskular (Yuhana et al., 2008; Satyantini et al., 2016). Perlakuan P1 dilakukan dengan menyuntikkan larutan fisiologis sebanyak 0,1 mL/ekor. Perlakuan P2, P3, dan P4 dilakukan dengan penyuntikan ekstrak daun ciplukan dengan dosis $4 \%$ (v/v), 8\%(v/v), dan $12 \%(v / v)$ pada masing-masing ikan nila sebanyak 0,1 mL/ekor. Sedangkan perlakuan P5 tanpa penyuntikan (tanpa perlakuan). Jumlah ikan yang digunakan pada masing-masing ulangan terdiri atas 12 ekor ikan nila. Ikan dipelihara dalam akuarium dengan ukuran $90 \mathrm{~cm} \times 60 \mathrm{~cm} \times 50 \mathrm{~cm}$, selama 14 hari. Pakan yang diberikan berupa pakan komersil dengan kandungan protein sebesar 25\% Pakan diberikan sebanyak 2 kali sehari yaitu pada pukul 07.00 dan 16.00 WIB.

Rancangan yang digunakan adalah Rancangan Acak Lengkap (RAL) tunggal yang terdiri atas 5 perlakuan dengan 3 ulangan. Perlakuan yang diberikan (P) terdiri dari $\mathrm{P} 1=$ Kontrol positif (penyuntikkan dengan larutan fisiologis), $\mathrm{P} 2=4 \%(\mathrm{v} / \mathrm{v})(1 \mathrm{~mL}$ ekstrak ekstrak +24 
$\mathrm{mL}$ akuades), $\mathrm{P} 3=8 \%(\mathrm{v} / \mathrm{v})(2 \mathrm{~mL}$ ekstrak $+23 \mathrm{~mL}$ akuades), $\mathrm{P} 4=12 \%(\mathrm{v} / \mathrm{v})(3 \mathrm{~mL}$ ekstrak $+22 \mathrm{~mL}$ akuades), dan $P 5=$ Kontrol negatif (tanpa penyuntikan).

\section{Parameter Pengamatan}

Parameter darah yang diamati dalam penelitian ini adalah Total Leucocyte Count (TLC) dan aktivitas fagositosis. Pengambilan sampel darah dilakukan pada hari ke-0 sebelum ikan diinjeksi dan hari ke-1, 4, 7, dan 14 hari setelah diberi perlakuan. Pengambilan darah dilakukan menggunakan spuit $1 \mathrm{~mL}$ yang sudah diberi antikoagulan natrium sitrat 3,8\% Sampel darah diambil melalui intra-vena (Lengka et al., 2013). TLC dihitung menggunakan haemocytometer. Darah dihisap dengan pipet sampai skala 0,5 dan dtambahkan larutan Turk's sampai skala 11, pipet diayunkan membentuk angka delapan selama 5 menit hingga darah bercampur rata. Larutan tersebut kemudian diteteskan pada hemocytometer kemudian ditutup dengan gelass penutup (Blaxhall \& Deasley, 1973).

Aktivitas fagositosis dilakukan mengikuti prosedur yang telah dilaporkan sebelumnya oleh Utami (2009). Sebelumnya, sebanyak 0,05 mg ragi yang digunakan untuk uji aktivitas fagositosis diaktifkan dulu dengan penambahan 0,10 g gula pasir. Kemudian ditambahkan air yang telah dipanaskan dengan suhu $70^{\circ} \mathrm{C}$ sebanyak $25 \mathrm{~mL}$. Ragi ini berfungsi sebagai mikroorganisme, untuk melihat kemampuan aktivitas fagositosis. Secara ringkas, sebanyak $50 \mu \mathrm{L}$ darah dimasukkan ke dalam microtube, ditambahkan 50 ì ragi yang sudah diaktifkan. Suspensi ragi dihomogenkan dan diinkubasi dalam suhu ruang selama 15 menit, kemudian sebanyak 5 ì dibuat sediaan ulas dikeringkan di udara. Ulasan difiksasi dengan metanol selama 5 menit dan dikeringkan. Ulasan direndam dalam pewarna giemsa selama 15 menit, kemudian dicuci dengan air mengalir dan dikeringkan dengan tissue. Dihitung jumlah sel yang menunjukkan proses fagositosis dari 100 sel fagosit yang teramati.

Pengelolaan kualitas air dilakukan dengan penyiponan setiap 2 hari sekali dan pergantian air dilakukan sebanyak 30\% Parameter kualitas air yang diamati adalah suhu, derajat keasaman $(\mathrm{pH})$, dan oksigen terlarut (DO).

Data hasil pengamatan meliputi TLC, aktivitas fagositosis diolah menggunakan Ms.Excel 2010, kemudian dianalisis dengan menggunakan ANOVA. Hasil tabel sidik ragam yang menunjukkan pengaruh yang berbeda, dilanjutkan dengan uji duncan dengan taraf kepercayaan $95 \%$

\section{HASIL DAN BAHASAN}

\section{TLC (Total Leucocyte Count)}

Jumlah sel darah putih pada berbagai perlakuan dan rentang pengamatan ditunjukkan pada Gambar 1.

Pengamatan pada hari ke- 1 telah terjadi peningkatan leukosit. Perlakuan P4 $\left(12,60 \times 10^{8} \mathrm{sel} \mathrm{mL}^{-}\right.$ $\left.{ }^{1}\right)$ berbeda nyata $(P<0,05)$ dengan $P 1\left(3,88 \times 10^{8}\right.$ sel $\left.\mathrm{mL}^{-1}\right)$ dan P5 $\left(5,73 \times 10^{8} \mathrm{sel} \mathrm{mL}^{-1}\right)$, namun tidak berbeda nyata dengan P2 $\left(8,02 \times 10^{8} \mathrm{sel} \mathrm{mL}^{-1}\right)$ dan P3 $\left(8,21 \times 10^{8}\right.$ sel $\left.\mathrm{mL}^{-1}\right)$. Pengamatan hari ke-4, diketahui bahwa P4 $\left(18,51 \times 10^{8}\right.$ sel $\left.\mathrm{mL}^{-1}\right)$ berbeda nyata $(\mathrm{P}<0,05)$ dengan P1 $\left(6,11 \times 10^{8}\right.$ sel mL $\left.{ }^{-1}\right)$, P2 $\left(7,68 \times 10^{8} \mathrm{sel} \mathrm{mL}^{-1}\right), \mathrm{P} 3$ $\left(1,64 \times 10^{8} \mathrm{sel} \mathrm{mL}^{-1}\right)$, dan P5 $\left(3,90 \times 10^{8} \mathrm{sel} \mathrm{mL}^{-1}\right)$.

Pengamatan hari ke-7 setelah diberi perlakuan, $\mathrm{P} 4$ $\left(16,18 \times 10^{8} \mathrm{sel} \mathrm{mL}^{-1}\right)$ tidak memberikan respon yang berbeda nyata dengan P1 $\left(17,02 \times 10^{8} \mathrm{sel} \mathrm{mL}^{-1}\right)$ tetapi berbeda nyata $(P<0,05)$ dengan $P 2(v / v)\left(6,56 \times 10^{8}\right.$ sel $\left.\mathrm{mL}^{-1}\right)$, P3 $\left(7,35 \times 10^{8} \mathrm{sel} \mathrm{mL}^{-1}\right)$, dan P5 $\left(4,75 \times 10^{8} \mathrm{sel} \mathrm{mL}^{-}\right.$ 1). Pengamatan pada hari ke-14 setelah diberi perlakuan diketahui bahwa P4 $\left(12,43 \times 10^{8} \mathrm{sel} \mathrm{mL}^{-1}\right)$ berbeda nyata $(\mathrm{P}<0,05)$ dengan $\mathrm{P} 1\left(4,85 \times 10^{8} \mathrm{sel} \mathrm{mL}^{-1}\right), \mathrm{P} 2(7,12 \times$ $\left.10^{8} \mathrm{sel} \mathrm{mL}^{-1}\right)$, P3 $\left(7,90 \times 10^{8} \mathrm{sel} \mathrm{mL}^{-1}\right)$, dan P5 $(6,72 \times$ $\left.10^{8} \mathrm{sel} \mathrm{mL}^{-1}\right)$.

Dosis $12 \%(\mathrm{v} / \mathrm{V})(\mathrm{P} 4)$ memberikan respons yang berbeda nyata $(P<0,05)$ dibandingkan kontrol negatif di semua pengamatan. Respons ini disebabkan adanya bahan aktif berupa flavonoid, saponin, dan tanin dalam ekstrak daun ciplukan (Effendi \& Harti, 2014). Bahan aktif yang masuk segera dikenali oleh ikan sehingga pada hari ke-1 ikan langsung memproduksi leukosit. Peningkatan leukosit ini diawali ketika masuknya ekstrak daun ciplukan (antigen) ke dalam tubuh ikan. Antigen adalah semua benda asing yang masuk ke dalam tubuh ikan di luar bagian dari tubuh ikan sendiri. Namun, antigen yang masuk yaitu berupa ekstrak daun ciplukan ini tidak berbahaya bagi tubuh ikan karena tidak bersifat patogen. Metode injeksi yang diberikan juga diduga menjadi penyebab responsifnya ikan terhadap antigen. Hal ini didukung oleh Olga \& Fatmawati (2013) yang menyebutkan bahwa metode injeksi merupakan metode yang efektif untuk antigen masuk ke dalam tubuh secara sistemik, yaitu melalui pembuluh darah dan beredar ke seluruh tubuh, sehingga respons yang diberikan akan semakin cepat.

Dosis 12\%(v/v) merupakan dosis ekstrak ciplukan yang paling tinggi yang digunakan pada penelitian ini. Dosis yang semakin tinggi menyebabkan respons (peningkatan leukosit) yang dibentuk juga akan semakin banyak. Penelitian yang dilakukan oleh 


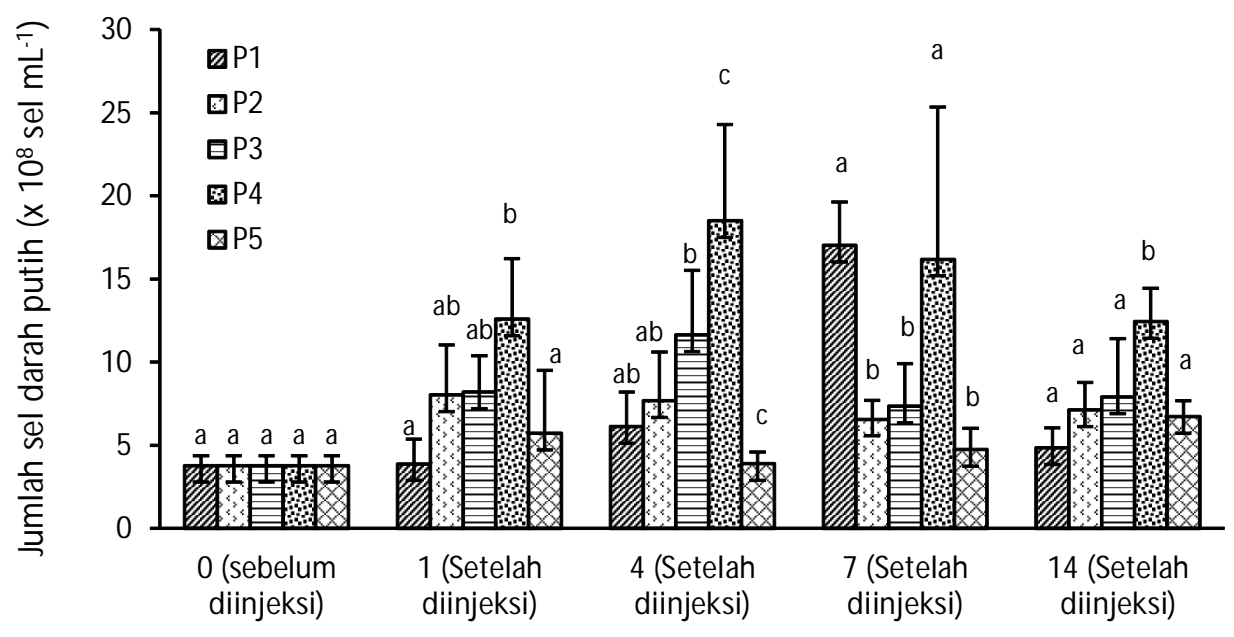

Hari pengamatan (Observation days)

Gambar 1. Total leukosit ikan nila pada berbagai perlakuan ( $P 1=$ kontrol positif, $\mathrm{P} 2=4 \%(\mathrm{v} / \mathrm{v}), \mathrm{P} 3=8 \%(\mathrm{v} / \mathrm{v}), \mathrm{P} 4=\mathrm{P} 3=8 \%(\mathrm{v} / \mathrm{v})$, dan $\mathrm{P} 5=$ kontrol negatif).

Figure 1. Total leucocyte count of nile tilapia in the various treatments $(\mathrm{P} 1=$ Positive control, $\mathrm{P} 2=4 \%(\mathrm{v} / \mathrm{v}), \mathrm{P} 3=8 \%(\mathrm{v} / \mathrm{v}), \mathrm{P} 4=8 \%(\mathrm{v} / \mathrm{v})$, and $\mathrm{P} 5=$ negative control).

Satyantini et al. (2016) menggunakan ekstrak air panas mikroalga Spirulina platensis yang diberikan secara injeksi juga memberikan respons peningkatan leukosit tertinggi pada perlakuan 20\% Dosis 20\% merupakan dosis tertinggi yang digunakan pada penelitian tersebut.

Peningkatan leukosit di semua perlakuan bekerja optimal pada hari ke-4. Hal ini sesuai dengan pendapat Effendi \& Harti (2014) yang mengatakan bila antigen pertama kali masuk ke dalam tubuh, terjadilah respons imun humoral yang ditandai dengan dihasilkannya antibodi (IgM) 6-7 hari setelah pemaparan. Respons pembentukan antibodi merupakan respons imun humoral yang artinya ketika terpapar antigen, ikan lebih dahulu akan melalui respons imun secara selular. Respons imun selular biasa terjadi 1-5 hari setelah pemaparan (Effendi \& Harti, 2014).

Penurunan jumlah leukosit terjadi pada hari ke-7 dan ke-14. Hal ini berkaitan dengan lama dosis bereaksi di dalam tubuh. Menurut penelitian Anderson \& Siwiski (1993), menggunakan glucan dan chitosan dengan cara pemberian disuntik atau direndam pada ikan mengalami penurunan kualitas efek obat pada hari ke14 dan ke-21. Penurunan ini juga diduga karena ikan tidak terpapar patogen sehinggga ikan akan berhenti memproduksi leukosit secara berlebihan dan kembali menuju keadaan normal.
Jumlah leukosit pada ikan yang normal menurut Angka et al. (1985) berkisar antara 2-15 (x 1075el mL ${ }^{-1}$ ) atau pada penelitian ini $\left(3,78 \times 10^{8} \mathrm{sel} \mathrm{mL}^{-1}\right)$. Pemberian ekstrak daun ciplukan secara injeksi memberikan efek positif terhadap peningkatan total leukosit. Hakikatnya ikan yang terpapar patogen juga akan mengalami peningkatan jumlah leukosit. Peningkatan ini terjadi untuk mengeliminasi patogen yang masuk, sehingga jumlah leukosit yang diproduksi oleh tubuh ikan akan langsung termanfaatkan. Berbeda halnya dengan peningkatan leukosit yang terjadi ketika diberikan ekstrak daun ciplukan, ini akan menyebabkan ikan memproduksi leukosit sebelum terjadinya paparan penyakit, sehingga ikan lebih tanggap apabila terpapar patogen. Menurut Efendi \& Harti (2014), ciplukan mengandung senyawa saponim dan flavonoid yang bersifat imunostimulator yang dapat membangkitkan respons imun.

\section{Aktivitas Fagositosis}

Aktivitas fagositosis (\% ikan nila pada berbagai perlakuan dan berbagai rentang pengamatan ditunjukkan pada Gambar 2.

Sistem pertahanan alamiah selain neutrofil (leukosit granular), yaitu sel-sel fagositik yang terdiri atas monosit dan makrofag. Makrofag merupakan monosit matang yang mampu memfagosit 100 


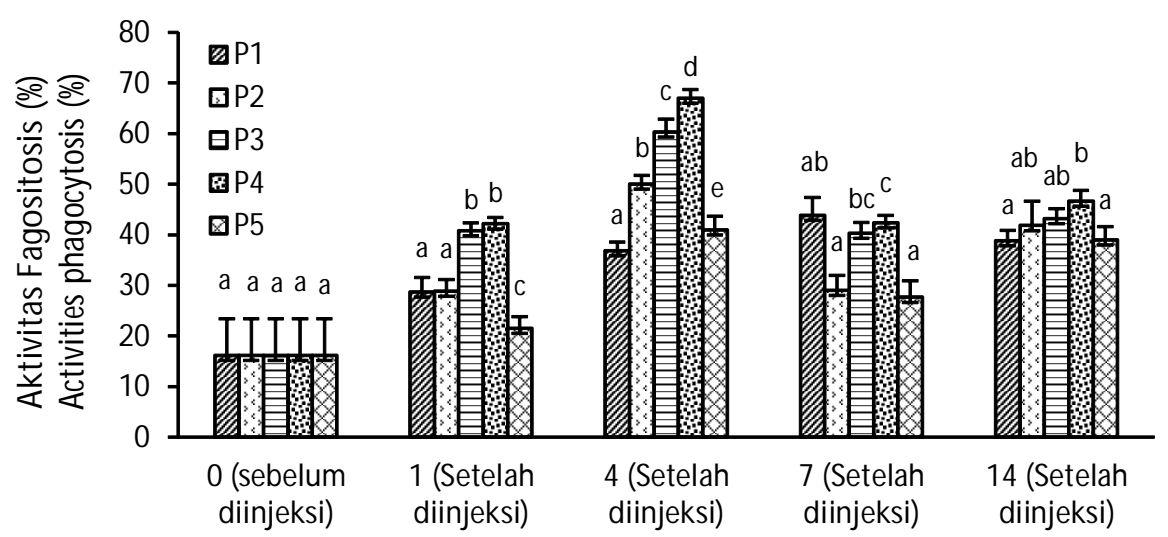

Hari pengamatan (Observation days)

Gambar 2. Aktivitas fagositosis ( $\%$ ikan nila pada pada berbagai perlakuan $(\mathrm{P} 1=$ kontrol positif, $\mathrm{P} 2=4 \%(\mathrm{v} / \mathrm{v}), \mathrm{P} 3=8 \%(\mathrm{v} / \mathrm{v}), \mathrm{P} 4=12 \%(\mathrm{v} / \mathrm{v})$, dan $\mathrm{P} 5=$ kontrol negatif).

Figure 2. Activities phagocytosis $(\%)$ of tilapia in the various treatments $(\mathrm{P} 1=$ positive control, P2 $=4 \%(\mathrm{v} / \mathrm{v}), \mathrm{P} 3=8 \%(\mathrm{v} / \mathrm{v}), \mathrm{P} 4=12 \%(\mathrm{v} / \mathrm{v})$, and $\mathrm{P} 5=$ negative control).

bakteri. Monosit berfungsi sebagai fagosit terhadap benda-benda asing, termasuk antigen. Aktivitas fagositosis biasa dijadikan parameter untuk menentukan sistem ketahanan tubuh ikan. Aktivitas fagositosis pada pengamatan hari ke-0 $(16,20 \%)$ merupakan kondisi normal ikan pada awal sebelum diberi perlakuan.

Pengamatan hari ke-1 P4 $(42,17 \%$ memberikan respon berbeda nyata $(P<0,05)$ dibandingkan dengan P5 $(21,50 \%$, P1 $(28,67 \%)$, dan P2 (28,83\%), namun tidak berbeda nyata dengan $\mathrm{P} 3(40,83 \%$. Pengamatan pada hari ke-4 berbeda nyata $(P<0,05)$ antar perlakuan. Aktivitas fagositosis tertinggi pada $\mathrm{P} 4$ yaitu sebanyak $67,00 \%$ Pengamatan pada hari ke-7 diketahui bahwa P4 $(42,33 \%)$ berbeda nyata $(P<0,05)$ dengan $P 5$ $(27,67 \%$, P2 (v/v) (34,00\%) dan P1 $(37,17 \%)$ tetapi tidak berbeda nyata dengan P3 (40,33\%). Pengamatan pada hari ke-14 P4 $(46 \%)$ berbeda nyata $(P<0,05)$ dengan P5 (38,83\%) dan P1 (39,00\%), namun tidak berbeda nyata dengan P2 (41,83\%) dan P3 (43,17\%).

Berdasarkan data pengamatan dapat diketahui bahwa pemberian ekstrak daun ciplukan secara injeksi ke tubuh ikan nila dapat meningkatkan aktivitas fagositosis. Uji lanjut duncan yang dilakukan diketahui bahwa dosis $12 \%(\mathrm{v} / \mathrm{v})(\mathrm{P} 4)$ memberikan respons yang berbeda nyata $(P>0,05)$ dengan kontrol negatif. Meningkatnya aktivitas fagositosis merupakan indikator peningkatan kekebalan tubuh. Alifuddin (1999) menyatakan peningkatan kekebalan tubuh dapat diketahui dari peningkatan aktivitas sel fagosit. Proses ini memberi perlindungan segera dan efektif terhadap infeksi.

Proses fagositosis menurut Anderson (1992), apabila terjadi kontak antara partikel dengan permukaan sel fagositosis. Membran sel kemudian mengalami invaginasi di mana dua lengan sitoplasma menelan partikel asing sehingga terkurung dalam sitoplasma sel, terletak dalam vakuola yang dilapisi membran (fagolisosom). Enzim pencernaan dan senyawa antimikroba yang terdapat dalam lisosom dapat mendegradasi sel mikroba yang tertelan.

Hasil penelitian ini juga menunjukkan bahwa ekstrak daun ciplukan dapat meningkatkan aktivitas fagositosis ikan nila terhadap ragi secara in vitro. Penelitian yang dilakukan oleh Fitrianti et al. (2011) diketahui bahwa ekstrak daun ciplukan memiliki efektivitas sebagai antimikroba terhadap bakteri MRSA secara in vitro. Penelitian serupa juga dilakukan oleh Sudarto (2009) diketahui bahwa ekstak daun ciplukan dengan konsentrasi 30\%mampu membunuh bakteri Pseudomonas aeruginosa dengan metode dilusi tabung dan penggoresan media NAP. Berdasarkan beberapa penelitian ini dapat diketahi bahwa ekstrak daun ciplukan memiliki sifat antimikroba.

Menurut Fitrianti et al. (2011), ekstrak daun ciplukan mempunyai sifat antimikroba. Sifat antimikroba ini disebabkan oleh adanya zat-zat aktif yang larut ketika daun ciplukan diekstrak menggunakan pelarut alkohol. Zat-zat aktif tersebut antara lain flavonoid, alkaloid, dan folifenol. 


\section{Sintasan (SR)}

Kelangsungan hidup ikan nila selama masa pemeliharaan 14 hari ditunjukkan pada Gambar 3.

Berdasarkan Gambar 3, diketahi bahwa kelangsungan hidup ikan nila tidak memberikan pengaruh yang berbeda nyata $(\geq 0,05)$ antar perlakuan selama masa pemeliharaan 14 hari. Kelangsungan hidup ikan nila pada penelitian ini bisa dikatakan cukup baik karena lebih dari 50\% Kelangsungan hidup yang cukup tinggi ini dikarenakan dosis perlakuan yang diberikan tidak terlalu tinggi, sehingga masih bisa ditoleransi oleh ikan. Ikan dipelihara dalam wadah yang terkontrol yaitu dalam ruangan sehingga fluktuasi kualitas air dapat ditekan. Menurut Taufik (1984), kualitas air sangat mempengaruhi kelangsungan hidup ikan, karena perubahan satu parameter kualitas air akan mempengaruhi parameter lainya.

\section{Kualitas Air}

Data kualitas air yang terukur selama masa pemeliharaan pada Tabel 1.
Berdasarkan data pada Tabel 1, dapat diketahui bahwa kualitas air yaitu suhu, pH, dan DO selama masa pemeliharaan 14 hari dalam kondisi yang baik. Hal ini dikarenakan parameter yang terukur telah memenuhi Standar Nasional Indonesia (SNI) pemeliharaan ikan nila. Suhu yang terukur selama pemeliharaan antar perlakuan sama yaitu berkisar antara $26-29^{\circ} \mathrm{C}$. Perubahan suhu akan mempengaruhi kecepatan perkembangan mekanisme pertahanan dan pembentukan antibodi, perubahan suhu dapat menjadi penyebab stres yang mempengaruhi kesehatan ikan (Abdullah, 2008). Oksigen terlalut yang terukur selama masa pemeliharaan yaitu 5,1-6,1 $\mathrm{mg} \mathrm{L}^{-1}$. Menurut Taufik (1984), kadar oksigen yang optimum untuk menjaga kesehatan ikan dalam media pemeliharaan harus berada dalam kisaran $6,5-12,5 \mathrm{mg} \mathrm{L}^{-1}$. pH yang terukur selama penelitian yaitu berkisa $6,9-7,5$ yang sesuai dengan standar nasional ikan nila. Kualitas air yang terukur selama penelitian dalam kondisi yang baik untuk mendukung status kesehatan ikan.

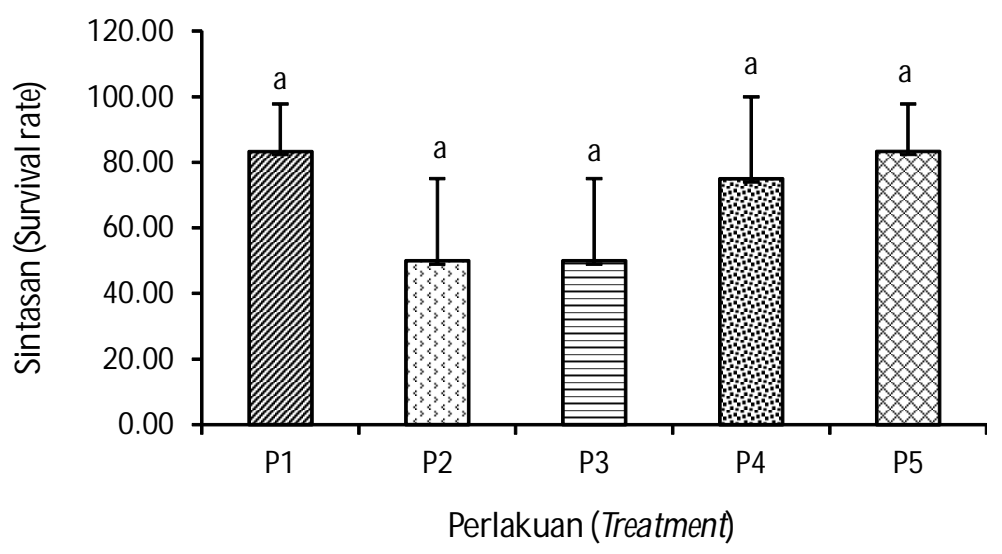

Gambar 3 Kelangsungan hidup ikan nila yang dipelihara selama 14 hari.

Figure 3. The survival rate of nile tilapia during 14 days rearing

Tabel 1. Data kualitas air ikan nila selama 14 hari pemeliharaan

Table 1. Water quality of nile tilapia during 14 days rearing

\begin{tabular}{cccc}
\hline Perlakuan & \multicolumn{3}{c}{ Parameter (Parameter) } \\
\cline { 2 - 4 } Treatment & Suhu (Temperature) $\left({ }^{\circ} \mathbf{C}\right)$ & $\mathbf{p H}$ & $\mathbf{D O}\left(\mathbf{m g ~ L}^{-1}\right)$ \\
\hline P1 & $26-29$ & $7.1-7.4$ & $6.1-6.3$ \\
P2 & $26-29$ & $7.1-7.3$ & $5.4-6.1$ \\
P3 & $26-29$ & $6.9-7.3$ & $5.1-5.4$ \\
P4 & $26-29$ & $7.1-7.5$ & $6.0-6.4$ \\
P5 & $26-29$ & $7.3-7.5$ & $5.7-5.8$ \\
SNI & $25-30$ & $6.5-8.5$ & $\geq 5.0$ \\
\hline
\end{tabular}




\section{KESIMPULAN}

Injeksi ekstrak daun ciplukan dengan dosis 4\%(v) v), $8 \%(\mathrm{v} / \mathrm{v})$, dan $12 \%(\mathrm{v} / \mathrm{v})$ sebanyak $0,1 \mathrm{~mL}$ per ekor secara intra muskular dapat memberikan pengaruh yang nyata terhadap sistem kekebalan tubuh ikan nila. Dosis $12 \%(v / v)$ merupakan dosis terbaik dalam meningkatkan jumlah leukosit dan aktivitas fagositosis. Jumlah leukosit dan aktivitas fagositosis pada hari ke-14 masing-masing sebesar $12,43 \times 10^{8}$ sel $\mathrm{mL}^{-1}$ dan $46,67 \%$

\section{UCAPAN TERIMA KASIH}

Ucapan terima kasih disampaikan untuk Jurusan Akuakultur, Universitas Bangka Belitung dan SMK N 4 Pangkalpinang atas fasilitas yang telah diberikan selama proses penelitian yang dilakukan.

\section{DAFTAR ACUAN}

Abdullah, Y. (2008). Efektivitas ekstrak daun paci-paci Leucas lavandulaefolia untuk pencegahan dan pengobatan penyakit MAS Motile Aeromonad Septicemia.Skripsi. Institut Pertanian Bogor: Fakultas Perikanan dan IImu Kelautan.

Alifuddin, M. (1999). Imunostimulasi pada hewan akuatik. Jurnal Akuakulur Indonesia, 1(2), 87-92.

Anderson, D.P. (1992). Immunostimulant, adjuvant and vaccine carrier in fish: Applications to aquaculture. Annual Review of Fish Diseases, 21, 281-307.

Anderson, D. P. \& Siwicki A.K. (1993). Basic haematology and serology for fish health programs. Paper presented in second symposium on diseases in asian aquaculture. Aquatic Animal Health and the Environment. Phuket, Thailand 185-202.

Angka, S.L., Wongkar G.T., \& Karwani, W. (1985). Blood picture and bacteria isolated from ulcered and crooked back Clarias bathrachus. Biotrop Special Publishing, (2), 129.

Arifin, M.F., Nurhidayati, L., Syarmalina, \& Rensy. (2009). Formulasi edible film ekstrak daun sirih (Piper betle L.) sebagai antihalitosis. Kongres IImiah, 17, 7-9.

Astuti, S. (2016). Uji aktivitas antioksidan ekstrak kloroform daun tomat (Solanum lycopersicum I.), daun cabai merah (Capsicum annum I.) dan daun ciplukan (Physalis angulata I.) dengan metode dpph. skripsi. Universitas Sebelas Maret, Fakultas Matematika dan IImu Pengetahuan.

Blaxall \& Deasley, K.W. (1973). Dasley: Routine Haematological Methods for Use With Fish Blood. Journal of Fish Biology, p. 577-581.
Effendi, N. \& Harti W. (2014). Identifikasi aktivitas imunoglobulin M (Ig.M) ekstrak etanolik daun ciplukan (Physalis minima linn.) pada mencit. Jurnal Kesehatan, 7, 353-359.

Fitrianti, D.A.R., Noohamdani, A.S., \& Setyawati, S.K. (2011). Efektivitas ekstrak daun ciplukan sebagai antimikroba terhadap methicilli-resistant Staphylococcus aureus in vitro. Jurnal Kedokteran Brawijaya, 26(4), 212-214.

Lengka, K., Manopo, H., \& Kolopita, M.E.F. (2013). Peningkatan respon imun non spesik ikan mas (Cyprinus carpio L) melalui pemberian bawang putih (Allium sativum). Budidaya Perairan, 1(2), 21-28.

Olga \& Fatmawati. (2013). Efikasi rute vaksin Aeromonas hydrophilaasb-01 pada ikan gabus (Ophiocephalus striatus). Fish Scientiae, 4(6), 138-140.

Pasaribu, W., Sammy, N.J., Longdong, \& Joppy, D.M. (2015). Efektivitas ekstrak daun pacar air (Impatiens balsamina L.) untuk meningkatkan respon imun non spesifik ikan nila (Oreochromis niloticus). Jurnal Budidaya Perairan, 3(1), 83-82.

Payung, C.N. \& Hengky, M. (2015). Peningkatan respon kebal non-spesifik dan pertumbuhan ikan nila (Oreochromis niloticus) ssmelalui pemberian jahe, (Zingiber officinale). Jurnal Budidaya Perairan, 1(3), 12.

Satyantini, W.H., Agustono, Arimbi, Emy, K.S., Budi, M., \& Lina, W.A. (2016). Peningkatan respon imun spesifik ikan gurami pasca pemberian ekstrak air panas mikroalga Spirulina platensis. Jurnal Vateriner, $17,349$.

Sudarto. (2009). Sensivitas Ekstrak Daun Ceplukan sebagai Antimikroba terhadap Pseudomonas aeruginosa. Skripsi. Universitas Brawijaya: Malang.

Taufik, P. (1984). Faktor kualitas air dapat mempengaruhi timbulnya suatu penyakit pada ikan. Majalah Pertanian. Jakarta.

Utami, W.P. (2009). Efektivitas ekstrak paci-paci (Leucas lavandulaefolia) yang diberikan lewat pakan untuk pencegahan dan pengobatan penyakit Motile Aeromonas Septicemia (MAS) pada ikan lele dumbo (Clarias sp.).Skripsi. Institut Pertanian Bogor, Fakultas Perikanan dan Ilmu Kelautan.

Yuhana, M., Normalia, I., \& Sukenda. (2008). Pemanfaatan ekstrak bawang putih (Allium sativum) untuk pencegahan dan pengobatan pada ikan patin (Pangasianodon hypothalmus) yang diinfeksi Aeromonas hydrophila. Jurnal Akuakultur Indonesia, 7(1), 95-97. 